\title{
The Role of Bottom-up Initiatives in Waterfront Development in Venice, Italy Case Study: The Venetian Arsenal
}

\author{
Jasna Cizler \\ e-mail: cizlerj@gmail.com
}

\author{
Stefano Soriani \\ Ca' Foscari University of Venice, Department of Economics, Italy \\ e-mail:soriani@unive.it
}

\begin{abstract}
The paper explores the process of redevelopment of Venetian waterfront areas through the initiatives of the local civil and creative sector. The important aspect of the research is the investigation of the role of these initiatives in protecting the heritage and the common good from the dominantly commercial development and unsustainable forms of tourism. The hypothesis is that non-institutional initiatives have the capacity, as well as the need to protect and use underused heritage buildings, and that they can influence and improve the results of the activation of these places through providing the innovations that would contribute to adapting the current planning practice. The research methodology is qualitative and combined: the main research method was a case study of policy and practice related to the activation of the Venetian Arsenal. The research consisted of the review of previous research and literature, field work at the chosen location, participating in events related to the research topic, meetings with experts and interviews with relevant actors. The aims of the research were: to investigate the current policy and practice regarding the activation of unused waterfront sites; to explore the role of bottom-up initiatives in this process; to examine how the existing institutional framework relates to such innovative initiatives; and to examine the limitations of this process and the possibilities for its improvement.
\end{abstract}

Key words: urban regeneration, adaptive reuse, naval heritage, local community, sustainable tourism, resilience. 


\section{Introduction}

The traditional instruments of urban planning are increasingly powerless in dealing with new challenges. Significant number of unused and derelict heritage buildings in city centers indicates that there is a need for changing the approach to their management. There is a need for innovative participation practices - such as temporary use, greater flexibility and greater involvement of non-institutional initiatives. The hypothesis is that non-institutional initiatives (of the civil and creative sector) have the capacity (social and creative capital), as well as the need to protect and use underused heritage buildings, and that they can influence and improve the results of the activation of these places through providing the innovations that could contribute to adapting the traditional planning models.

The question of inclusion of bottom-up initiatives in the process of heritage protection and urban planning is of particular importance for Venice, being a UNESCO designated world heritage site, which at the same time faces the pressure and negative effects of mass tourism, significant decline of the population and the loss of non-tourism related activities. The historic city center faces transformations such as the change of use of buildings and replacement of traditional production activities. One of the negative effects is endangering of the local cultural and social identity and integrity. As Caroli and Soriani (2017) report, this process is characteristic for many historical waterfronts, where modernization processes have marginalized local cultures and historical community-based values. They recognize that resilience requires new approaches to planning: 'Bottom-up, more inclusive and place-based initiatives are needed to improve livability and resilience of communities and cities on water' (Caroli and Soriani, 2017). Regeneration of the areas in the historic centre of Venice that are unused, but have significant cultural and social value, such as the Arsenal, could be recognized as a chance to 'give' the city back to its citizens.

Formally, the public policy in Venice recognizes the value of participation. Tools, such as the ' 1973 Special Law for Venice' and 'The Management Plan for the World Heritage property', have been developed to protect the heritage and are based on a participatory approach. In some periods (e.g. 2012-2015), together with other actors, the Municipality developed a series of projects related to public participation and opening of the Arsenal to the citizens. However, many obstacles remain today and there is a resistance of the local government to the input coming from the local organisations: 'Venice's local administration is primarily focused on consulting with economic interest groups and is notably reluctant to interact with community groups' (Forum Futuro Arsenale, 2016)

\section{Theoretical background}

The Venetian Arsenal (Arsenale di Venezia) is a former production site and an example of preindustrial, naval heritage. Its buildings, infrastructure, machinery and intangible heritage, represent the remains of industrial culture that have historical, technological, social, scientific and architectural value, giving it the unique character 
and place identity (TICCIH, 2003). Aside from being a landmark in the city, places such as the Arsenal are also related to the identity of the city and its residents, representing an example of progress and pride for the local community, whose interest is to protect and use it. In 1980s industrial heritage, its preservation and reuse started to be recognized in international documents and charters (e.g. Council of Europe, $1987^{1}$ ). It has become internationally recognised that reuse of heritage buildings can lead to the improvement of places, image creation and economic growth, especially in situations when these sites are located near the water (Landry, 2001, 2005; Bianchini and Parkinson, 1993).

Waterfronts have been a research topic since the 1960s (see for example: Bruttomesso, 1993; Marshall, 2004). Formerly seen as symbols of urban crises, waterfront areas are increasingly recognised as a potential market resource and re-vitalised (Minca \& Soriani, 2000). However, revitalised urban waterfronts of postindustrial cities around the world are often built as an expression of universal urban policy, resulting with being very similar to each other and being linked to competitiveness and neoliberal urbanization (Brownill, 2013).

At the same time, instrumentalisation of culture in public policy and urban regeneration has been a subject of criticism. Large urban regeneration projects often fail to succeed in producing non-commercial spaces, which would be used by the local community and which would respond to their needs (Evans, 2009a,b). Evans (2009a,b) emphasizes the role of users as initiators of activities in adapting places according to the needs of the community, instead according to those made by policy makers. Site-based resistance movements, artist and community intervention in the regeneration process, bottom-up and DiY activation of unused buildings and the culture of squatting, are some manifestations of these needs. The role and importance of non-institutional initiatives in urban regeneration can be seen in urban social/grassroots movements, a number of which has accepted the concept of right to the city as the basis of their activities, implying that the city should be understood as a product of all residents, who have the right to use and influence the process of creating them regardless of the ownership (Lefebvre, 1996; Harvey, 2009, 2013). Civil society and organised communities have a significant role in achieving this right. They enable citizens to articulate, defend and advocate their interests. Being significant for local people, place identity and personal identity, cultural/industrial heritage is recognized as a public good, a value to which all humans are entitled without paying and exclusion.

The role of non-institutional actors in waterfront development (including the community resistance to change), has been well documented (see for example: Pinder, 1981). The process of urban waterfront change is strongly influenced by a variety of community groups operating on a local scale, but promoting globally-relevant ideas about environmental sustainability (Hoyle, 1999):

1 Council of Europe (1987) Recommendation no. $R$ (87) 24 of the Committee of Ministers to Member States on European industrial towns. 
'Whereas short-term financial gain may be the primary objective of a developer, the affected communities are concerned with the wider implications for socioeconomic and political change, and ultimately with the sustainability of the changes introduced on whatever scale' (Hoyle, 1999)

As Hoyle (1999) shows on the example of Canadian waterfronts, community groups provide a significant source of ideas, they can seek to modify or redirect the character of redevelopment, and can influence the pace and pattern of change and development.

Changes in public attitudes towards the industrial heritage and the recognition of its values are associated with the protests and initiatives which originated from the volunteers and enthusiasts beyond the formal institutions ${ }^{2}$. Self-organized groups are a source of innovations and can have important roles in preserving and activating heritage buildings: through research, initiation of activities and drawing attention to the site and its potentials, as well as through protecting the heritage from demolition and dominantly commercial interests and solidarity with the marginalized groups in the process of urban regeneration. Since traditional instruments in urban planning are increasingly powerless in dealing with the new challenges, a solution for unused spaces is increasingly found in innovative models, such as the temporary use and greater flexibility when making plans (Oswalt, Overmeyer, Misselwitz, 2013; Lehtovouri and Ruoppila, 2012; Senatsverwaltung für Stadtentwicklung Berlin, 2007). These innovations are particularly important in challenging situations, where traditional public institutions did not manage to find the solution for the site and where regular real estate development is not an option (Lehtovuori and Ruoppila, 2012; Senatsverwaltung für Stadtentwicklung Berlin, 2007). Examples of reuse of former industrial heritage buildings from other European countries show that bottom-up initiatives can have a significant role in preserving buildings, but also in improving public places, image of the place and contributing to activities relevant for the local community ${ }^{3}$.

\section{Research methodology}

Applied research methodology was qualitative and combined. The main research method was a case study of policy and practice related to the activation of the Venetian Arsenal. The research consisted of the review of previous research and literature, field work at the chosen location, participating in events related to the

2 Example of this is industrial heritage preservation in the United Kingdom. Cossons (2008: 253) writes about this issue: 'Initiatives by innumerable voluntary bodies and preservation groups have taken several hundred industrial sites and buildings into their care. This has been a movement which the UK government encouraged, in part because it had not the capacity itself to meet the challenge, in part out of recognition that locally-based initiatives stood a greater chance of success in the long term'.

3 For example in Serbia (Cizler, 2019), Austria (Cizler, Pizzera and Fischer, 2014), Czech Republic (Cizler, 2014) and Germany (Oswalt, Overmeyer, Misselwitz, 2013). 
research topic (public meetings, conferences, round tables), meetings with experts and interviews with relevant actors from the public, private and civil sector. In-depth interviews represented an important component of the research process and they focused on how relevant actors understand their own circumstances related to the use of the place, heritage protection, communication with other actors and institutions. The following types of interviews were conducted:

- Topic guide interview and informal conversations - used in the initial stages of the research;

- $\quad$ Structured open-ended questions interview - the main type of interview used in the research.

Respondents were chosen by using the snowball sampling method - initial primary data sources nominated another potential primary data sources to be used in the research. The pattern that was used is exponential non-discriminative snowball sampling, where the first subject recruited to the sample group provided multiple referrals. Each new referral was explored until primary data from sufficient amount of samples were collected. The research involved conducting 16 interviews with experts from the public, private and civil sector ${ }^{4}$.

Two groups of questions were created for the needs of the interviewing -1 . for experts from public institutions (local government, planning and heritage protection), and 2 . for the respondents from civil sector who are related to unused waterfront areas. The questions were formulated to examine the institutional framework for the activation of these areas and buildings, the use of innovative approaches, the cooperation between actors, the role of non-institutional actors, as well as their impact on the formal system and building activation itself. Data analysis showed in which ways these actors activate and use abandoned areas and buildings, the innovations they apply and the response of the formal institutional system to it.

$\mathbf{4}$ The structured interviews were conducted with: 1) Filipo Lovato (architect, City of Venice, Directorate of Land Development and Construction, Urban Design of the Historical Center and Islands); 2) Fabrizio D'Oria (Director of Communication and Events, Vela Spa) and Marta Moretti (External relations, Vela Spa); 3) Elena Zambardi (Communication and external relations, Consortio Venezia Nuova); 4) Roberto D'Agostino (Councilor for Urban Planning 1994/2001 and Strategic Planning 2001/2005, director of the company Arsenale di Venezia SpA 2007-2014); 5) Alberto Bernstein (Conzortio Venezia Nuova 1988-2009, Thetis SpA 20092011, former member of the FFA); 6) Francesco Calzoaio (architect and landscape architect, president of Venti Cultura, member of the FFA and Faro Venezia); 7) Roberto Falcone (President of the FFA until October 2018) and Jane da Mosto (Co-founder \& Executive director of We Are Here Venice, member of the FFA); 8) Andrea Mariotto (IUAV, expert in public participation); 9) Prosper Wanner (Faro Venezia, former consultant of the City of Venice, member of the FFA).

The informal conversations were conducted with: 1) Marina Dragotto (Municipality of Venice); 2) Luca Pegoraro (Navy); 3) Federica Cavallo (Ca' Foscari); 4) Mauro Cannone (Ca' Foscari); 5) Matteo Giannasi (Ca' Foscari); 6) Giulio Grillo (Rebiennale); 7) Barbara Pastor (Vice-president of the FFA until October 2018) and 8) Jane da Mosto (Co-founder \& Executive director of We Are Here Venice, member of the FFA). 


\section{Case study: Venetian Arsenal - Overview and discussion of the research results}

\subsection{Historical background and overview of the main actors}

Among many civil sector initiatives to protect and activate unused areas in Venice, those related to the Arsenal are particularly interesting, since this complex has been the subject of interest of both, citizens and experts, for decades 5 . Despite its significance and a number of debates, studies and projects, many parts of the Arsenal are still derelict, unused and not open to the public.

The City of Venice was founded in the 5th century and became a major maritime power in the 10th century. The City is spread over 118 small islands and today represents an extraordinary architectural masterpiece and the UNESCO World Heritage property. Under huge pressure from tourism, the transformations of the historic city centre are mainly caused by the replacement of housing with commercial, tourismrelated activities and services, which endanger its identity and cultural and social integrity ${ }^{6}$.

The Venetian Arsenal (Arsenale di Venezia) is a shipyard founded in the 12th century, and it was the source of the Venetian Republic's maritime power and one of the world's greatest production sites. The Venetian Republic (La Serenissima) reached the peak of its power in the 15th century, when the Arsenal employed thousands of men (Faraone, n.d.) The decline of the Venetian Republic started in the 1600s. Activities and employment in the Arsenal gradually decreased and the complex was destroyed at the end of the 18th century by the French. The production restarted during the Habsburg period and stopped again in the mid 19th century when Austria transferred its production activities to Istria. The Italian Royal Navy started to use it in 1866 (Faraone, n.d.).

5 Other civil sector initiatives for protection and activation of unused areas in Venice are related to the following places and groups: S.a.L.E. Docks, Laboratorio Morion, Caserma Pepe, Centro Sociale Rivolta, Gasometri di San Francesco della Vigna, San Biagio island and Poveglia per Tutti.

${ }^{6}$ UNESCO website http://whc.unesco.org/en/list/394 
Figure 1.

Position of the Arsenal in Venice

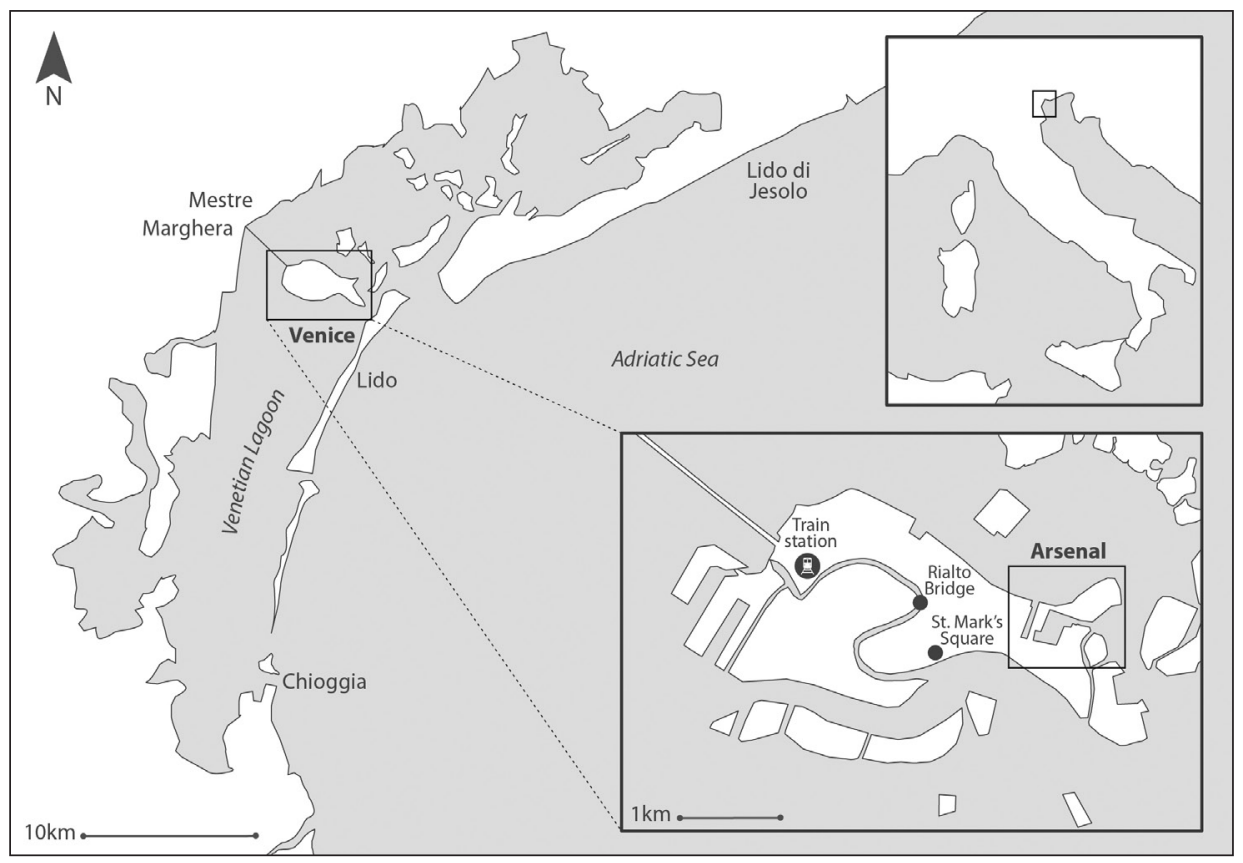

Source: J. Cizler, 2019

The decline of Arsenale started after the WWI. Between the 1960s and 1980s, there were many initiatives for the recovery of the complex, but nothing took place on the operational level, resulting with the abandonment of a considerable part of the Arsenal (Menichelli, 2014). The gradual restoration of abandoned buildings began in 1980s by the Superintendency and through the funds of the Ministry for Cultural Heritage $^{7}$ (Menichelli, 2014). The first big reuse was for the 1st International Architecture Exhibition by the Venice Biennale (La Biennale di Venezia) in 1980. The Biennale in 1999 obtained a concession of 50,000 $\mathrm{m}^{2}$ in the south-eastern part of the Arsenal and had contributed to the restoration of buildings together with the Superintendency (Menichelli, 2014). Company Thetis SpA had a significant role in the 1990s when there were no other initiatives for recovering the buildings. This maritime technology company has been located in the Arsenal since 1997 and is a good example of how the space in the Arsenal can be reused for the activities similar to those for which it was originally built.

7 The Ministry for Cultural Heritage and Activities (Ministero per i Beni e le Attività Culturali$M i B A C$ ) through its local offices (Regional Directorates and Superintendencies) performs the institutional tasks of protection and preservation of cultural heritage. 
Still, the deterioration of the northern part was serious at the end of the 1990s, and in 2000 Magistrato alle Acque di Venezia started 10 years of restorations in this area ${ }^{8}$ (Menichelli, 2014). The detailed plan of the Northern Arsenal (Piano Particolareggiato Arsenale Nord) was approved in $2003^{\circ}$. Soon after that, the company Società Arsenale di Venezia SpA was established by the state-owned agency Agenzia del Demanio and the Municipality of Venice, with the aim to revitalise the complex ${ }^{10}$. The focus was on the northern part of the Arsenal, as the southern was the property of the Italian Navy until 2012, and in the following years numerous buildings were revitalised and reused. Conzortio Venezia Nuova started to use the space in the Arsenal in 2006 and CNR-ISMAR in 2009. In 2009 new measures for the protection of the Arsenal were incorporated by the Superintendence, replacing those brought in 1986 (Menichelli, 2014).

After the acquisition of a large part of the Arsenal in 2013 by the Municipality of Venice, Arsenale di Venezia SpA was liquidated and Ufficio Arsenale was established to deal with the regeneration of the complex. The Arsenal today occupies 48 ha (Citta di Venezia, 2014) and is used for a mix of science\&technology, arts\&culture, defense and manufacturing activities. Most of the space is used by the following actors: Ministry of Defence - Italian Navy (Ministero della Difesa - Marina Militare), Venice Biennale, Consorzio Venezia Nuova, public transport provider Azienda del Consorzio Trasporti Veneziano (ACTV), CNR-ISMAR (National Research Council Institute of Maritime Science) and Thetis SpA. 41\% of the Arsenal is owned by the Italian Navy, while the Municipality of Venice owns 59\% (Citta di Venezia, 2014). Vela SpA is in charge of the management of the area of the Arsenale Nord on behalf of the City of Venice, while the Navy has the control over all the water areas in the complex. Consorzio Venezia Nuova consists of large national and local construction companies and is the concessionary of the Ministry of Infrastructures and Transport for the implementation of the measures to safeguard Venice and the Lagoon. The Consortium has concessions in the Arsenal area, where it carried out the MOSE project - engineering system for the defense of Venice against the flooding. Until recently, the plan included the activities for the maintenance of the MOSE gates in the northern part of the Arsenal. However, MOSE project has been a subject of controversy, due to delays, cost overruns and corruption, which is why it has met resistance from many actors. The project started in 2003 and is still not fully completed, while floods remain a constant threat to the city.

8 Magistrato alle Acque di Venezia (Venice Water Authority) was a local branch of the Ministry of Infrastructure and Transport, and was in charge of the protection of the Venetian Lagoon. It has been replaced by Provveditorato Interregionale alla Opere Pubbliche per il Triveneto.

9 Other plans that deal with the Arsenal are Documento Direttore (Preliminary plan) of 2015 (updated in 2016, the last document about the Arsenal, a strategic document, brought by Ufficio Arsenale and the urban planning sector of the City of Venice); and Piano Particolareggiato Arsenale Sud (Masterplan for the Southern Arsenal) of 2005.

$1051 \%$ of this company was owned by the Italian State and $49 \%$ by the Municipality of Venice. 
Aside from the actors coming from the public and private sector, actors from the civil sector are particularly important in researching the Arsenal, especially those who are actively engaged in issues related to the way public space and common goods are used and managed. Forum Futuro Arsenale - FFA is a non-profit association established in 2012 as a coordinating body for the interests of over 30 local groups, to monitor and contribute to the revitalisation of the Arsenal. Groups which are part of the FFA are: Ambiente Venezia; Amici del Nuovo Trionfo; Archeoclub Venezia; ARCO (Associazione Residenti Castello Orientale); Arzanà; Associazione Culturale Olivolo-Auser; Associazione Culturale Venezia Arte, Cultura \& Turismo; Associazione galleggiante 'Il Caicio'; Associazione Nazionale Guide Turistiche; Associazione Settemari; Associazione Vela al Terzo; Assonautica Venezia; Bochaleri - Associazione di Ceramisti Veneziani; Canottieri Giudecca; Comitato Festa della Sensa; Comitato per la Restituzione dell'Arsenale a Venezia; Compagnia della Marineria Tradizionale "Il Nuovo Trionfo"; Coordinamento Io Decido; Ecoistituto del Veneto Alex Langer; El Felze; Faro Venezia; Fondamente; Fondazione Bucintoro; Istituto Nazionale di Bioarchitettura - sezione di Venezia; Italia Nostra - sezione di Venezia; Laguna nel Bicchiere; Remiera Francescana; Società di Mutuo Soccorso Carpentieri e Calafati; Venti di Cultura; and We Are Here Venice. Although gathered around the common goal - to participate actively in the regeneration process and to ensure the protection of the Arsenal, these organisations have various backgrounds. Among FFA members there are professional and amateur rowers, sailors, university professors, lawyers, engineers, architects, artisans, sociologists, art historians, as well as residents of the neighboring district - Castello. Similarly, the topics individual organisations deal with are different, but related to Venice. Many of the organisations focus on boats and sailing (e.g. Amici del Nuovo Trionfo, Arzanà, Associazione galleggiante 'Il Caicio', Associazione Vela al Terzo, Assonautica Venezia, Canottieri Giudecca, Fondazione Bucintoro and Remiera Francescana), while others focus on cultural heritage (Italia Nostra; Archeoclub Venezia), tourism (Associazione Nazionale Guide Turistiche), heritage communities (Faro Venezia) and participation (Coordinamento Io Decido).

\subsection{Problems and limitations in managing and protecting the Venetian Arsenal}

The period when the local administration was most engaged in activities related to the Arsenal, was 2012-2015. According to the information on the web-site of the City of Venice, it was recognized that the Arsenal area has the potential to play 'a future pivotal role in the economic and social development of the city and of the whole metropolitan area of Venice' (Citta di Venezia, 2014). The city was committed to the 'comprehensive urban regeneration programme' for the area, aiming at 'giving a different point of view of the actual city economic sector mainly based on tourism' (Citta di Venezia, 2014). The office which was in charge for the Arsenal at that time (Ufficio Arsenale), aimed to regenerate the area and make it a lively part of the city by openness, a diverse and inclusive community and to define the participation tools to share with the civil society (Citta di Venezia, 2014). 
According to Ms Marina Dragotto from the Municipality of Venice, the period 20122015 was characterised by a number of initiatives from both the civil society and the municipality: meetings, projects such as Arsenale Aperto, patrimonial walks, participatory days and temporary events. There was a determination to follow the Faro Convention, supported by the Council of Europe (M. Dragotto, personal interview, Jan 29, 2018). However, when the city governance changed in 2015 and the Ufficio Arsenale was closed, the activities and interest of the Municipality for the Arsenal stopped. The relationship between the Municipality and non-institutional initiatives has weakened significantly.

Figures 2. and 3.

Entrance gate to the Arsenal (Porta Magna) and the northern part of the complex (Arsenale Nord) with one of the old cranes and the tower (Torre di Porta Nuova) in the background
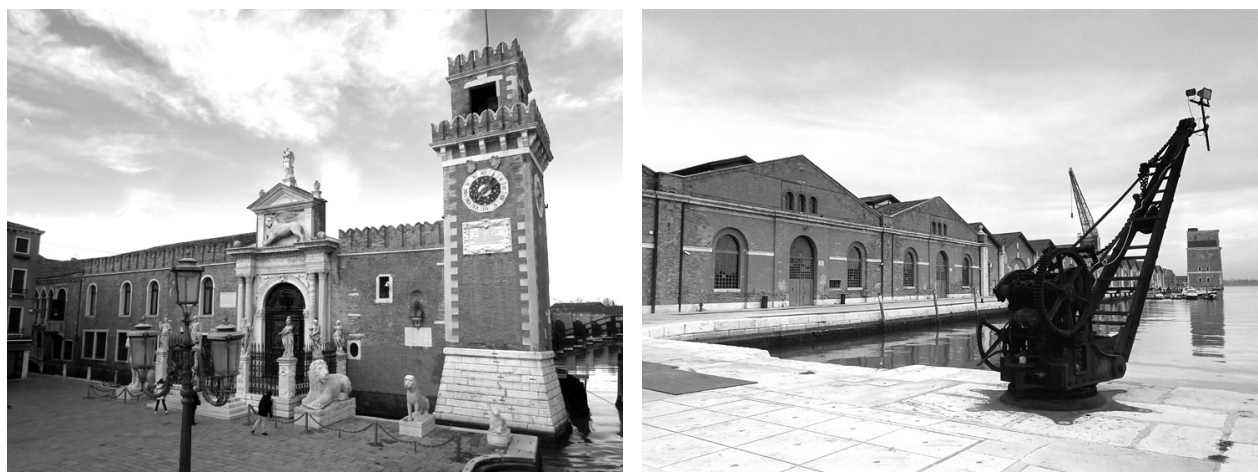

Author: J. Cizler, 2018

Mr. Roberto D'Agostino, former director of the public company Arsenale di Venezia SpA, sums up the main problems related to the complexity of the Arsenal recovery: heritage issues; issues related to finding desirable and compatible functions; financial - the costs of recovery; management problems (organization of the numerous subjects that operate and that would have to operate in the Arsenal); assignment and turnover problems (who chooses users, how they reciprocate); design, procurement, construction management problems; long-term sustainability problems (R. D'Agostino, personal interview, March 20, 2018). Mr. D'Agostino explains how the process of management of the Arsenal is influenced by different actors and their interests and aims:

'It should be borne in mind that the various players in the field have never conceived of the Arsenal as a public good, but as a private good to be used for their own ends. The Navy, the Venezia Nuova Consortium and the Biennale Foundation, which are the three main recipients of parts of the Arsenal, have always acted as private subjects, placing their particular interest in the general objectives' (R. D'Agostino, personal interview, March 20, 2018). 
Figure 4.

Map of the Arsenal and its surrounding in 2018

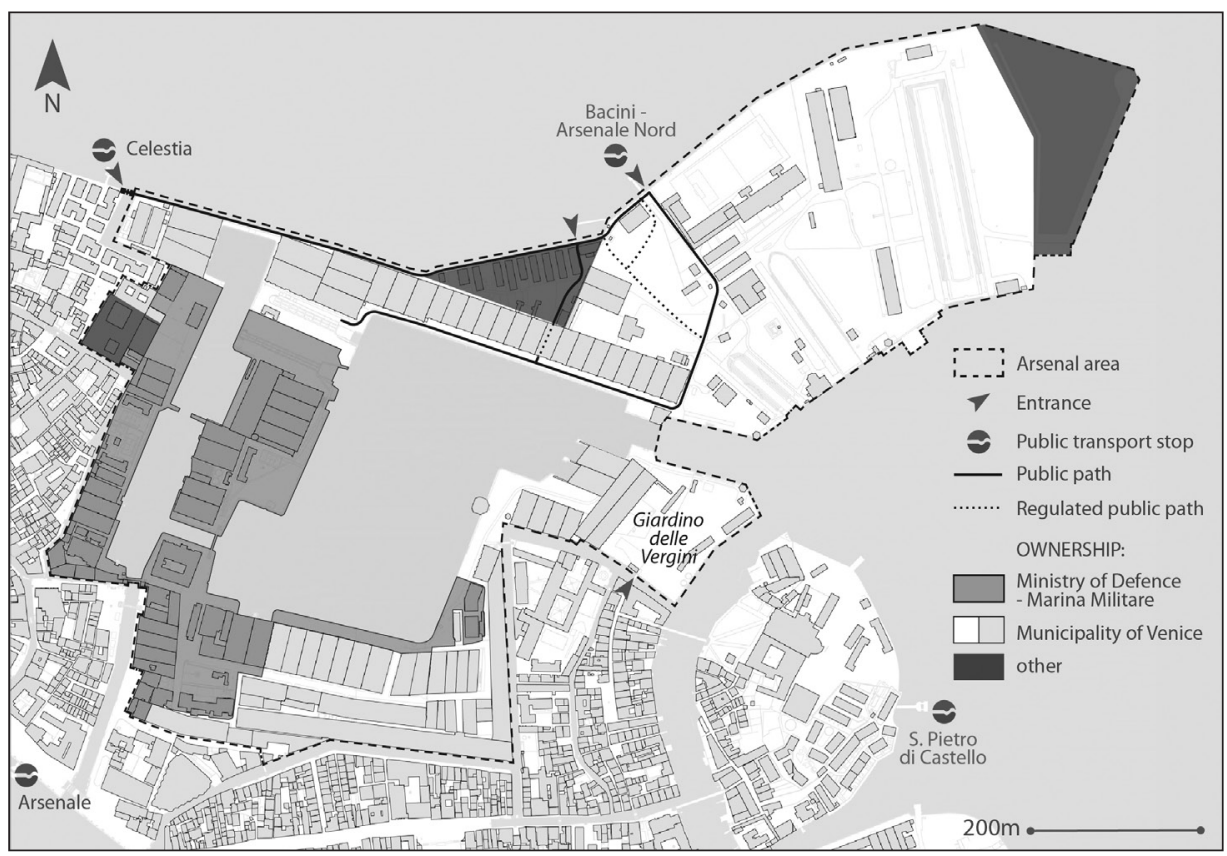

Author: J. Cizler, according to Citta di Venezia, 2015

The problems on the site itself include the lack of basic services (water, electricity, insulation), while at the same time buildings are protected as heritage, making the introduction of new uses complicated and expensive. Most of the actors lack financial means to restore the buildings.

Accessibility of the Arsenal has been an issue for a very long time. Initially built with the intention to separate the production activities from the rest of the city by its high walls, this complex remains isolated after the production stopped. Aside from the physical separation, some of the space users, such as the Navy and Biennale, have continued the policy of the restricted access to this area (e.g. access to the parts used by Biennale is limited to the exhibition periods and is subject to entrance fee). As many similar cases show, accessibility is an important issue in waterfront regeneration and is needed in creating successful projects:

'What is also evident from the experience of many other waterfronts is that successful regeneration, whatever its nature, will similarly require good access. This will be essential in order to create interest and demand for sites in the complex, as well as to assist the daily movement of employees and visitors after regeneration' (Clark, Pinder, 1999).

The accessibility of the Arsenal has increased in the last few years thanks to the recovery of some areas and buildings, mainly in the northern part, as well as due 
to the introduction of the pedestrian bridge leading to the northern entrance. The space managed by the municipality is occasionally rented for public and private events such as the carnival and Arte Laguna exhibition, which brings a number of visitors to the area.

Figure 5.

High walls surrounding the northern part of the Arsenal and a pedestrian path next to them

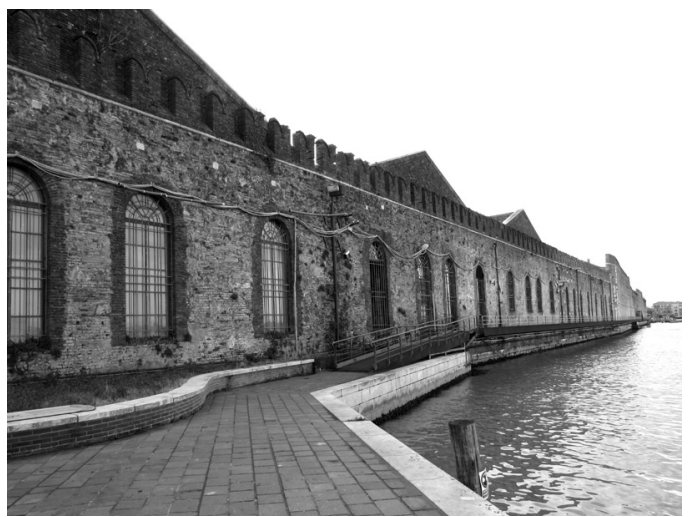

Source: J. Cizler, 2018

\section{Figure 6.}

One of the unused buildings in Arsenale Nord

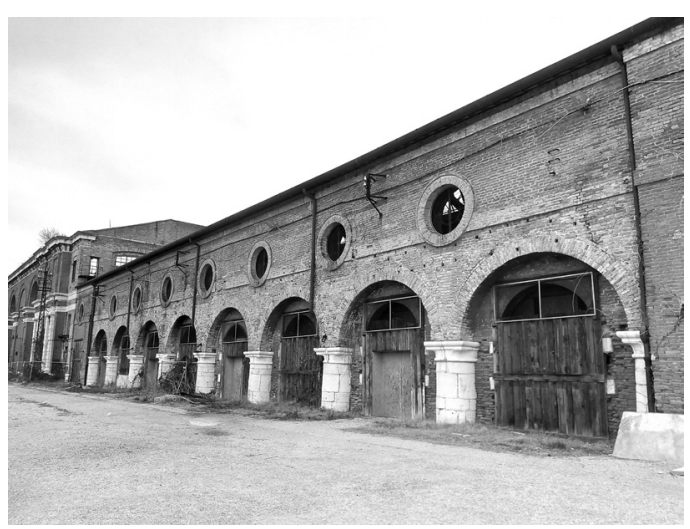

Source: J. Cizler, 2018

Since there is no obligation to make a thorough participatory process, like in some of the Italian regions, the decision to involve citizens in decision making process or not depends on the willingness of the current government. Therefore, the decision making process has changed with changes in the governing structure and the cooperation has decreased in the last few years. Letters and requests for meetings from non-institutional actors are often left unanswered by the municipality, leading to the lack of communication between these two sides. The fact that most of the non-institutional initiatives and their members represent the political opposition to 
the current government of the city, does not help build dialogue and cooperation. Local experts are aware of this issue. For example, Mr. Filipo Lovato, architect in the Office for detail planning of the historical centre of the City of Venice draws attention to the changes in public policy in Venice:

'All around the city, also in Mestre, the real politics regarding the space that the City gives to the associations has changed in the last few years. They try to get money from the space users. My opinion is that it is not a right way to manage public spaces. The richness is not only economic but also social' (F. Lovato, personal interview, March 7, 2018).

Mr. Alberto Bernstein, environmental protection specialist who worked for both Consortio Venezia Nuova and Thetis, and was a member of the Forum Futuro Arsenale, describes difficulties in participating in the current decision-making process and affecting the system with bottom-up initiatives:

'Before, you could push ideas and change the way decisions are made inside the politics by political pressure. Now this does not work. We are quite stuck because you make a proposal, but the proposal does not come out of your group of people that are aware of the problem and opportunities. We try to discuss in the City Council where people are elected, but it absolutely does not work. The bottom-up initiative works when you have a kind of an open system. In this now, the bottom-up does not really work. It is a difficult situation because you are visible, but not effective' (A. Bernstein, personal interview, February 14, 2018).

Organisational problems are related to the lack of trust between public institutions and civil society, which makes it difficult to create cooperation. Only few actors think that the city is working for the commons and not everyone thinks that cooperation is necessary nor wants to cooperate. Participation is part of the rhetoric and marketing - everyone is talking about it, but there is no real conviction (P. Wanner, personal interview, February 21, 2018). There is a lack of interest among the citizens for this issue:

'It has been quite difficult to push the issue towards a larger audience than the small audience of people that are interested in all Venetian issues. Even if there is a number of people who are interested in participation, the vast majority is not. A bulk of the people are not interested in what is happening. This administration relies on the silence of the bulk in governing the city. My opinion on this city is that the administration does not want to get involved in difficult problems' (A. Bernstein, personal interview, February 14, 2018).

The event organised in April 2015 involved different actors and topics, including a survey done for potential investors. Mr. Andrea Mariotto, expert in public participation, was engaged by the municipality as a facilitator in 2015. He describes this process: 
'It was the first time the local people could see what kind of investors could be involved in this process. For me, it was interesting as a realistic way of looking at this part of city. But some people don't want to look at private investors. A lot of people were angry, against this way of thinking. They did not understand. The people said 'you are trying to sell the Arsenal while we do not have a mayor'. They were frightened, did not want to meet again and everything stopped' (A. Mariotto, personal interview, March 20, 2018).

The heterogeneity of involved actors can be seen as a potential and is necessary for making better projects. Mr. Mariotto provides several reasons for this:

'Ideas are strong when you have the heterogeneity of people involved and many different actors supporting it. If you have only one kind of people, it is unsustainable from many points of view. The Arsenal is so huge that you cannot imagine future without thinking about someone from the side who would put not only money, but also ideas. You can't only think about how to preserve, you have to think about how to change it. When you transform it, you need to call for new people, new uses. Participation is not something rhetorical, it is a way to make a project better. It is not enough to represent only the interests of citizens. If you want to use this kind of heritage in a good way, you have to anticipate not only what local people say, but you have to deal with some other actors, private and public' (A. Mariotto, personal interview, March 20, 2018).

Despite the existing knowledge and expertise, 'the transition from protest-driven actions to constructive execution of ideas is not straightforward' (Forum Futuro Arsenale, 2016). The harmonizing of different actors' interests, even when they belong to the same group, and making a concrete proposal can be a complex issue:

'The point is that with this system you can build up a movement on a specific issue, where many people are against something, but for different reason, stay together. When you try to shift from opposition to proposition, to proposal, things get very difficult. Because making a proposal needs work and then there are many different points of view. So I think that this is one of the key points in citizen participation. Shifting from opposition to proposition is the point' (A. Bernstein, personal interview, February 14, 2018). of participation, in his opinion only a small number of FFA members gets involved in discussion and making of the proposal, which makes it difficult to create it and is the reason why he decided not to be the part of the FFA anymore:

'Active participation does not happen. Everybody would like, it seems sensible, but it does not happen, even in the advocacy group. You have to find a different way. You have to be around the table with maps and documents and look each other in the eye and try to give form to a proposal. There is a lot of exchange of short information, but difficult to build up a way for sharing complex information. To be able to give a proposal, you need this' (A. Bernstein, personal interview, February 14, 2018). 
The problems of the use of space are related to the fact that some of the current uses (such as the exclusive parties managed by the public company in the Arsenale Nord) are seen as inappropriate by the local organisations, which are not able to use the space for non-profit activities. The reason could be the lack of communication and cooperation. Ms. Elena Zambardi, Communication and external relations representative from Conzortio Venezia Nuova, suggests that some part of the Arsenal area could be used by civil sector organisations:

'It would be very nice to have other people, groups, and activities in this area because it is very closed and isolated, so that it becomes more integrated in the city. If Forum Futuro Arsenale found some activity, it would be very good. We could stay all together' (E. Zambardi, personal interview, March 8, 2018).

Most interview respondents agree that there is a need to keep the Arsenal as a place unrelated to tourism. Mr. Bernstein points out that:

'Venice has a lot of opportunities for people working in the tourism sector or trade related to tourism, and very little opportunities for other activities, because the space is too expensive' (A. Bernstein, personal interview, February 14, 2018).

Unfortunately, people often have no capacity to imagine something outside tourism (P. Wanner, personal interview, February 21, 2018).

\subsection{The role and significance of civil sector initiatives in activating and protecting the Venetian Arsenal}

According to Caroli and Soriani (2017), building resilience of communities and cities on the water, requires new approaches to planning and governance and involvement of both economic and social actors. Authors write that traditional top-down, approaches are no longer appropriate and that bottom-up, more inclusive and place-based initiatives are needed (Caroli and Soriani, 2017) They underline that one of the central points in building resilient communities is raising citizens' awareness about the potential of cultural heritage. The safeguarding and promotion of cultural heritage is important not only for economic development, but also for communities' identity and resilience (Caroli and Soriani, 2017) Cecconi (2017) examined how new bottom-up approaches are being designed and implemented to address the issue of resilience in Venice. He underlines that resilience cannot rely exclusively on top-down approaches, but requires the involvement of citizens and social groups. Non-institutional subjects at this time could and should play a role in stimulating institutional actors to assume their responsibilities (R. D'Agostino, personal interview, March 20, 2018) Mr. Mariotto reaches a similar conclusion:

'The potential of non-institutional actors is great. Because institutional actors are now really lacking ideas, we have to enlarge as much as we can this realm of non-institutional actors. We have to look at actors that are not involved and we have to involve them' (A. Mariotto, personal interview, March 20, 2018). 
Numerous local organizations are active in the process of questioning and influencing the way public space and common goods are managed and used in Venice. Forum Futuro Arsenale - FFA, has produced a conceptual framework for the development of the Arsenal which proposes an innovative form of management of this area. Forum Futuro Arsenale suggests flexibility and redevelopment of the Arsenal in phases, as 'precisely planned mega-projects have been disappointing countless times' (FFA, 2016). FFA states that there is a need for introducing innovative statute formulations and organizational models ${ }^{11}$. They proposed the Foundation for Participation as a management structure for the Arsenal. This organizational form would function as an intermediary between the State and market sectors; it would combine characteristics of traditional foundations with those of non-profit associations and it would include the local community in the institutional role (FFA, 2016). FFA also proposes the promotion of traditional crafts, fostering of the local creativity, encouraging the collaboration, monitoring and evaluation through indicators that are not purely profit based, but instead measure social and environmental sustainability (such as the Benessere Equo Sostenibile) (FFA, 2016).

Giardino delle Vergini is a public garden opened for public a few years ago, thanks to the initiative of the experts related to the FFA. Hidden behind the high walls in a secluded corner of the city, it is rarely visited, as many Venetians are not aware that it is open to public.

Figure 7.

Giardino delle Vergini - public park in the Arsenal

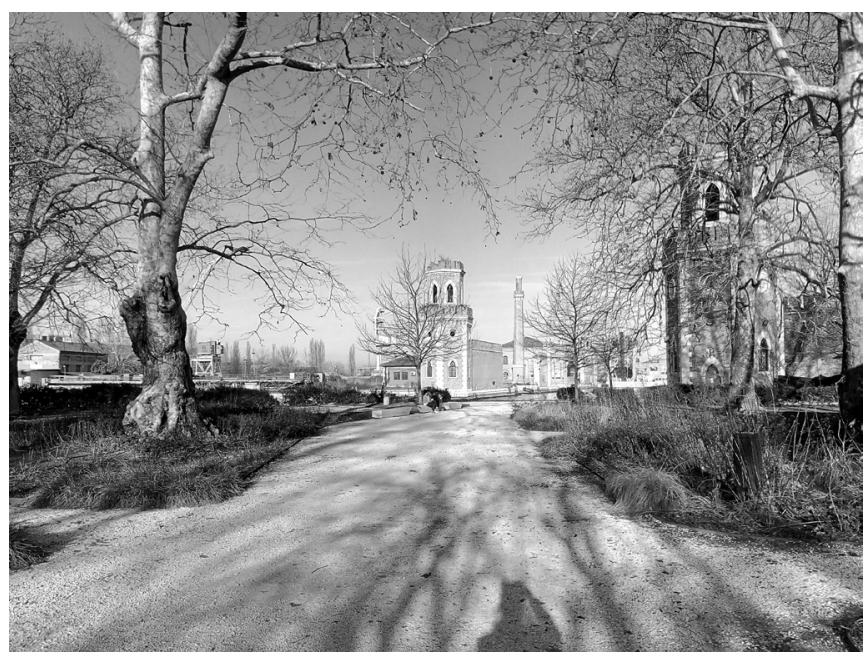

Source: J. Cizler, 2018

11 FFA mentions an example from the experience of Comune di Chieri (Piedmont), where municipal regulations for public participation have been adopted to formally recognize the institutional role of the 'heritage community' (defined in the Faro Convention by the Council of Europe, 2005) and its commitment to the 'common good' (Forum Futuro Arsenale, 2016). 
Figure 8.

Arsenale Nord during the Biennale

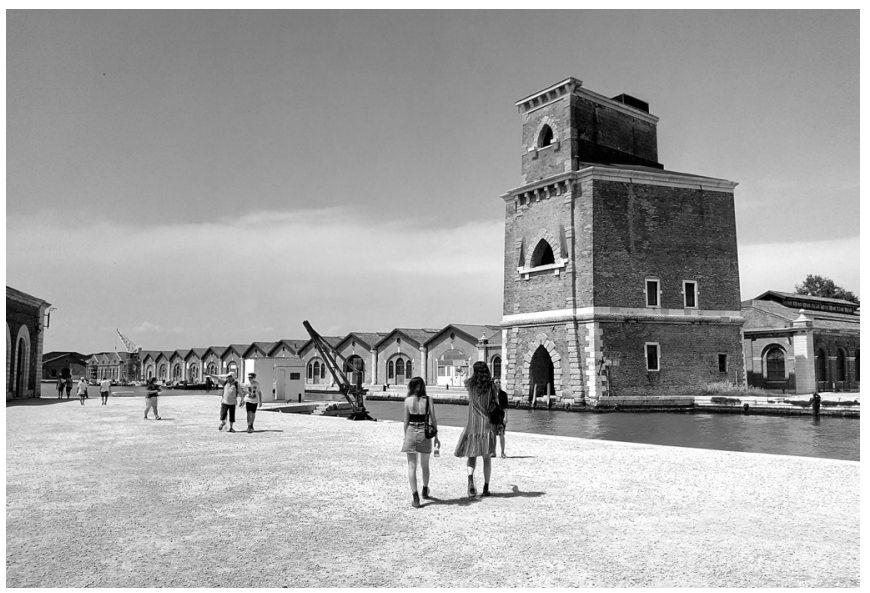

Source: J. Cizler, 2018

Organisation Faro Venezia is a part of the FFA and was established in 2008. Its aims are the promotion of the Faro Convention and its implementation in the Venetian context. The Faro Convention promotes a wider understanding of heritage and its relationship to communities and society:

'The Convention encourages us to recognize that objects and places are not, in themselves, what is important about cultural heritage. They are important because of the meanings and uses that people attach to them and the values they represent' (Council of Europe, 2005).

17 Member States of the Council of Europe have signed the Convention. Venice was the first Italian city that became interested in this Convention and translated it to Italian (Wanner, 2018). According to this Convention, heritage community consists of people who value specific aspects of cultural heritage which they wish, within the framework of public action, to sustain and transmit to future generations. Everyone, alone or collectively, has the right to benefit from cultural heritage and to contribute towards its enrichment (Article 2, Council of Europe, 2005) ${ }^{12}$. The activities of the

$\mathbf{1 2}$ In the management of cultural heritage, the Parties undertake to: develop the legal, financial and professional frameworks which make possible a joint action by public authorities, experts, owners, investors, businesses, non-governmental organisations and civil society; develop innovative ways for public authorities to co-operate with other actors; respect and encourage voluntary initiatives which complement the roles of public authorities; encourage non-governmental organisations concerned with heritage conservation to act in the public interest (Article 11, Council of Europe, 2005). According to the Article 12 - Access to cultural heritage and democratic participation, the Parties undertake to encourage everyone to participate in the process of identification, study, interpretation, protection of cultural heritage; recognise the role of voluntary organisations both as partners in activities and as constructive critics of cultural heritage policies; and take steps to improve access to the heritage (Council of Europe, 2005). 
Faro Venezia included heritage walks (the first one was in 2008 and was related to industrial reuse on the island of Giudecca). Since 2013 they have cooperated with FFA, Municipality and other actors, organising events such as the Arsenale Aperto event in 2014 and 2015 (the website of the Faro Venezia).

In 2013 part of the Arsenal became owned by the City of Venice thanks in large part to the action of the associations gathered in the FFA and the protests they organised (Arsenale alla Citta, meaning 'The Arsenal to the City') (Wanner, 2018, P. Wanner, personal interview, February 21, 2018; J. Da Mosto and R. Falcone, personal interview, March 28, 2018). At that time, different actors with different interests and visions, aimed to get the Arsenal for their use (Conzorzio Venezia Nuova, Biennale, Military, etc.). The City used the pressure coming from the citizens and associations, who had a strong capacity to create events and appear in the media, to influence the Government to get the Arsenal property (P. Wanner, personal interview, February 21,2018$)$.

In 2014 Mr. Wanner, expert for the interpretation of the Faro Convention, founding member of the Faro Venezia, started an 18 month collaboration with the Arsenal office of the City of Venice, for the application of the Faro Convention. The goal was to use this Convention as a frame of reference in the process of conversion of the Arsenal ${ }^{13}$ : 'The goal was not to resolve the various conflicts in progress but to reorganize them in a constructive and cooperative way in the general interest' (Wanner, 2018):

'For me, it was a good opportunity to try to create the link between institutions and society' (P. Wanner, personal interview, February 21, 2018).

The process was organized around 4 phases (Wanner, 2018):

1. Sharing the knowledge of the Arsenal. This phase implied the development of a 'virtual urban center' and making information about the Arsenal accessible online;

2. Mutual understanding between different actors interested in the future of the Arsenal. This phase implied making patrimonial communities visible. The City of Venice asked the Faro Venezia to organize heritage walks in the Arsenal;

3. Constructive dialogue between actors. This phase implied the organization of the annual event Arsenale Aperto (Open Arsenal), which included all actors and 20,000 participants each year (2014 and 2015). Mr. Wanner describes this process:

13 The initiative to use the Faro Convention as a frame of reference was influenced by the FFA, who declared themselves as a heritage community and wanted to implement the Convention. 
'We tried to create the cooperation between all the stakeholders and to involve all of them. For example, when we organised Arsenale Aperto, it was the first time that all stakeholders were at the same table: FFA, the City, Biennale, Consortio Venezia Nuova... The idea was to use this event and begin to create dialogue between them' (P. Wanner, personal interview, February 21, 2018).

4. Common redefinition of the management framework for the future of the Arsenal.

Even though the project was successful and some progress was made, 18 months later the political situation (arrest of the mayor, MOSE project controversies, election of the new mayor) led to the closing of the Arsenal office and the common framework for cooperation between actors has not been established.

One of the most recent successes of the non-institutional actors involves the decision to move the facilities for the maintenance of the MOSE project from the Northern Arsenal to Marghera, an industrial borough of Venice located on the mainland. This decision was made at the end of 2018, after a long fight of Forum Futuro Arsenale to save this valuable historical area, by drawing attention to its significance and to the need to keep it accessible to the citizens. The member of the FFA dedicated to the protection of the heritage - Italia Nostra, had a role in this by informing representatives of the national institutions in charge of the heritage protection, and inviting them to visit the Arsenal earlier in 2018. They warned that having MOSE activities in the Arsenal would be unsustainable and contrary to its protection.

Forum Futuro Arsenale continues to monitor the situation in the Arsenal. Recent events include the organising of a picnic in Giardino delle Vergini and the Darsena Grande in March 2019, where people were invited to share their ideas and observations. Forum's active member - We Are Here Venice, conducted a research project in 2019, which resulted with a report 'How Was It For You', investigating the ways in which the Biennale affects the life in the city and serves the interests of its residents:

'The size and influence of the Biennale institution means it is, and will continue to be, crucial in determining the future of the city. The question is not whether Venice should host the Biennale: it is a significant reality. But should Venice be getting more from the Biennale, and vice versa? (We Are Here Venice, 2019).

The report is based on the observations, collected data, interviews and media reports. Some of the questions which have framed the investigation were:

- How can such a large temporary event become more sustainable in the context of the local economy and social dynamics?

- How can the Biennale aid the revitalisation process and the potential of the under-utilised northern area of the Arsenal, especially with regard to public access and everyday logistics?

- Can the Biennale continue its model of restoration but also release some spaces for local use or integrate more local productive activities in its business model, thereby expanding its connectivity to the local economy on a more continuous basis? (We Are Here Venice, 2019). 
Projects like this are important for stimulating the discussion between different actors, such as the Biennale, its exhibition curators and exhibitors.

\section{Conclusion}

The paper explored the process of redevelopment of the Venetian Arsenal through the initiatives of the local civil and creative sector. The focus of the research was the role of these initiatives in protecting the heritage from the dominantly commercial development and unsustainable forms of tourism, and in keeping them accessible to the local community. The research showed how non-institutional initiatives protect and use underused heritage buildings, and how they influence and improve the results of the activation of these places through providing the innovations which contribute to adapting the current planning practice. The results show that noninstitutional actors play a significant role in stimulating institutional actors to deal with relevant issues, by pointing to the problems, producing innovative solutions for them and stimulating cooperation between institutions and citizens. The research has showed that activities of the non-institutional actors and in particular, groups gathered around the association FFA, are similar to numerous other bottom-up initiatives, which have managed to improve the quality of the space through raising the awareness and through temporary use. The research stressed the importance of these initiatives and the need to involve them more actively in the official public policy, which would contribute to reducing the conflicts and improving the process of waterfront regeneration.

This paper is a result of the Post-Doc research conducted between December 2017 and June 2018 at Ca' Foscari University of Venice, Italy and supported by SUNBEAM - Erasmus Mundus Action 2 programme. 


\section{References}

1. Bernstein, A. (2018). [Personal interview], Feb 20.

2. Bianchini, F. and Parkinson, M. (ed.) (1993). Cultural Policy and Urban Regeneration: The West European Experience. Manchester: Manchester University Press.

3. Brownill, S. (2013). Just add water: waterfront regeneration as a global phenomenon, in: Leary, M. and McCarthy, J. (Eds.). The Routledge Companion to Urban Regeneration. London: Taylor \& Francis Ltd.

4. Bruttomesso, R. (Ed.) (1993). Waterfronts: A New Frontier for Cities on Water. Venice: International Centre Cities on Water.

5. Caroli, R. and Soriani, S. (2017). Foreword, in: Caroli, R. and Soriani, S. (Eds.). Fragile and Resilient Cities on Water. Perspectives from Venice and Tokyo. Newcastle upon Tyne: Cambridge Scholars Publishing.

6. Cecconi, G. (2017). Venice: Living with Water, Learning with Nature - A Regenerating Arena for Global Cities, in: Caroli, R., and Soriani, S. (Eds.). Fragile and Resilient Cities on Water. Perspectives from Venice and Tokyo. Newcastle upon Tyne: Cambridge Scholars Publishing.

7. Citta di Venezia (2014). Urban Regeneration Insights for the Renewal and Management of the Venice Arsenale, Background information, Workshop, May 30, 2014, Venice.

8. Citta di Venezia (2015). Documento Direttore per l'Arsenale di Venezia - 2015.

9. Cizler, J. (2019). Activation of Former Industrial Areas: Creative and Civil Sector as Main Actors in Overcoming the Institutional Limitations in Serbia. Sociology and Space, 57 (1): 23-44.

10. Cizler, J. (2014). The role of creative and civil initiatives in transforming post-industrial landscapes: A case study of industrial heritage re-use in Czech Republic. Facta Universitatis: Series Architecture and Civil Engineering, 12 (3): 207-219.

11. Cizler, J.; Pizzera J. and Fischer, W. (2014). Industrial heritage as a potential for redevelopment of post-industrial areas in Austria. ACEG+, Journal for Architecture, Civil Engineering, Geodesy and other related scientific fields, (2) 2014 2(1).

12. Clark, C. and Pinder, D. (1999). Naval heritage and the revitalisation challenge: lessons from the Venetian Arsenale. Ocean \& Coastal Management, 42: 933-956.

13. Cossons, N. (2008). Yesterday's Industry, Tomorrows Legacy, in: Primyslové dědictví / Industrial heritage edited by Benjamin Fragner. Prague: Research Centre for Industrial Heritage of the Czech Technical University, Technical Monuments Committee of the Czech Chamber of Certified Engineers and Technicians, Czech Union of Certified Engineers, 248-256.

14. Council of Europe (2005). Convention on the Value of Cultural Heritage for Society (Faro Convention). Available at: www.coe.int/en/web/conventions/full$\underline{\text { list/-/conventions/rms/0900001680083746. }}$.

15. D’Agostino, R. (2018). [Personal interview], March 20.

16. Da Mosto, J. (2018). [Personal interview], March 28.

17. Dragotto, M. (2018). [Personal interview], Jan 29.

18. Evans, G. (2009a). Creative spaces and the art of urban living, in: Edensor, T. and Millington, S. (Eds.). Spaces of Vernacular Creativity: Rethinking the Cultural Economy. London: Routledge. 
19. Evans, G. (2009b). Creative Cities, Creative Spaces and Urban Policy. Urban Studies, 46 (5\&6): 1003-1040.

20. Falcone, R. (2018). [Personal interview], March 28.

21. Faraone, A. (n.d.) The Arsenale of Venice. Available at: www.venicethefuture. $\mathrm{com} / \mathrm{schede} / \mathrm{uk} / 316 /$ ? aliusid=316.

22. Forum Futuro Arsenale (2016). The Venetian Arsenale and the City. Venice: Forum Futuro Arsenale.

23. Harvey, D. (2013). Rebel Cities: From the Right to the City to the Urban Revolution. London: Verso.

24. Harvey, D. (2009). Social Justice and the City. Athens, Georgia: The University of Georgia Press.

25. Hoyle, B. (1999). Scale and sustainability: the role of community groups in Canadian port-city waterfront change. Journal of Transport Geography, 7 (1999): 65-78.

26. Landry, C. (2001). The Creative City: A Toolkit for Urban Innovators. London: Earthscan.

27. Lefebvre, H. (1996). Writings on Cities. Oxford: Basil Blackwell.

28. Lehtovuori, P. and Ruoppila, S. (2012). Temporary uses as means of experimental urban planning. SAJ, 4: 29-54.

29. Lovato, F. (2018). [Personal interview], March 7.

30. Mariotto, A. (2018). [Personal interview], March 20.

31. Marshall, R. (Ed.) (2004). Waterfronts in Post-Industrial Cities. Taylor \& Francis.

32. Menichelli, C. (2014). The Arsenale yesterday and today. History of the complex in transformation, in: HAULuP. Heritage and Architecture of Urban Landscape under Production. Venice: IUAV.

33. Minca, C. and Soriani, S. (2000). Crafting the new spaces of postmodern urbanism: the 'bistoric waterfronts' as new social and functional places, Geographies of diversity. Italian perspectives. Roma: Società Geografica Italiana, 225-242.

34. Oswalt, P.; Overmeyer, K. and Misselwitz, P. (2013). Urban Catalyst: The Power of Temporary Use. DOM Publishers.

35. Pinder, D. A. (1981). Community attitude as a limiting factor in port growth: the case of Rotterdam, in: Hoyle, B. and Pinder, D. A. (Eds.). Cityport Industrialization and Regional Development: Spatial Analysis and Planning Strategies. Oxford: Pergamon Press.

36. Senatsverwaltung für Stadtentwicklung Berlin (2007). Urban Pioneers: Temporary Use and Urban Development in Berlin. Berlin: Jovis.

37. TICСIH (2003). The Nizhny Tagil Charter for the Industrial Heritage. Available at: http://ticcih.org/about/charter.

38. Wanner, P. (2018). L'Arsenale, 18 mesi di percorso Faro. Available at: https:// farovenezia.org/2018/02/10/larsenale-18-mesi-di-percorso-faro/.

39. Wanner, P. (2018). [Personal interview], Feb 21.

40. We Are Here Venice (2019). How Was It For You?. Available at: https://drive. google.com/file/d/1vaIiVqxMaXWo7NMNagH6T2lz8yjh9ws8/view.

41. Zambardi, E. (2018). [Personal interview], March 8. 
Prethodno priopćenje

Jasna Cizler

e-mail: cizlerj@gmail.com

\section{Stefano Soriani}

Sveučilište Ca' Focari u Veneciji, Odjel za ekonomiju, Italija

e-mail: soriani@unive.it

\section{Uloga 'bottom-up' inicijativa u razvoju priobalja u Veneciji, u Italiji - Studija slučaja: Venecijanski Arsenal}

\section{Sažetak}

Rad istražuje proces prenamjene priobalnih područja u Veneciji kroz inicijative lokalnoga civilnog i kreativnog sektora. Važan aspekt istraživanja predstavlja ispitivanje uloge ovih inicijativa u zaštiti baštine i zajedničkog dobra od dominantno komercijalnog razvoja i neodrživih oblika turizma. Hipoteza je da neinstitucionalne inicijative imaju kapacitet i potrebu da štite i koriste neiskorištene objekte kulturne baštine, i da mogu unaprijediti rezultate aktivacije ovih prostora, kroz osiguravanje inovacija koje doprinose prilagodbi postojeće planerske prakse. Metodologija istraživanja je kvalitativna i mješovita: glavna istraživačka metoda je studija slučaja politike i prakse aktivacije Venecijanskog Arsenala. Istraživanje se sastojalo od pregleda prethodnih istraživanja i literature, terenskog rada na odabranoj lokaciji, sudjelovanja u događanjima povezanim s temom istraživanja, kao i od sastanaka s ekspertima i intervjua s relevantnim akterima. Ciljevi istraživanja bili su sljedeći: istražiti postojeću politiku i praksu aktivacije neiskorištenih lokacija u priobalju; istražiti ulogu 'bottom-up' inicijativa u ovom procesu; istražiti kako se postojeći institucionalni okvir odnosi prema ovim inicijativama i ispitati ograničenja ovog procesa i mogućnosti za njegovo unaprjeđenje.

Ključne riječi: urbana obnova, adaptivna prenamjena, pomorska baština, lokalna zajednica, održivi turizam, rezilijentnost. 